\title{
Seed protectant potential of Mitracarpus villosus and Phyllanthus fraternus extracts on germinative capability of stored food grains
}

\author{
Adesina, J. M. ${ }^{1,2}$, Rajashekar, Y. ${ }^{2}$, Ofuya, T. I. ${ }^{3}$, Ashamo, M. O. ${ }^{4}$, Ileke, K. D. ${ }^{4} \&$ Mobolade-Adesina, T. E. ${ }^{5}$ \\ ${ }^{1}$ Department of Crop, Soil and Pest Management Technology, Rufus Giwa Polytechnic, P. M. B. 1019, Owo, Ondo State, Nigeria \\ ${ }^{2}$ Insect Chemical Ecology Laboratory, Institute of Bioresources and Sustainable Development, Department of Science and \\ Technology, Takyelpat, Imphal - 795001, Manipur, India \\ ${ }^{3}$ Department of Crop, Soil and Pest Management, Federal University of Technology, P. M. B. 704, Akure, Ondo State, Nigeria \\ ${ }^{4}$ Department of Biology, Federal University of Technology, P. M. B. 704, Akure, Ondo State, Nigeria \\ ${ }^{5}$ Department of Science Laboratory Technology, Rufus Giwa Polytechnic, P. M. B. 1019, Owo, Ondo State, Nigeria \\ Author for correspondence: moboladesina@ rugipo.edu.ng
}

\begin{abstract}
Summary: Seed storage is an essential post-harvest operation that decides the success of seeds viability and germination in next generation. The study explored Mitracarpus villosus and Phyllanthus fraternus extracts as bio-insecticides seed treatments on stored wheat and green gram seeds viability and germination. M. villosus and P. fraternus plants powder were sequentially extracted with solvents of increasing polarity (Petroleum ether, hexane, ethyl acetate, acetone, chloroform and methanol), concentrated and tested for insecticidal activity by fumigant toxicity. The extract which showed maximum activity, was selected for seed viability and germination test. Five replications each were made for the treatment and the control. The plant extracts strengthen the non-phytotoxic nature of plant products against seed viability and germination. Seeds treated with extracts $\left(50-400 \mu \mathrm{g} \mathrm{seed}^{-1}\right)$ did not lose their viability as it resulted in successful and normal germination within the range of $90-97.67 \%$ irrespective of the extracts concentration. While, seeds in control recorded 95.55 and $100 \%$ germination which were not significantly different $(\mathrm{P}>0.05)$ compared to the treated seeds. Based on findings from the study, potential exploitation of M. villosus and $P$. fraternus as food grains protectant in insect pest management strategies is recommended for the resource poor farmers. However, further investigations are suggested on biosafety and effects of the extracts on the organoleptic contents of the grains prior to consumption.
\end{abstract}

Adesina, J. M., Rajashekar, Y., Ofuya, T. I., Ashamo, M. O., Ileke, K. D., \& Mobolade-Adesina, T. E. (2019): Seed protectant potential of Mitracarpus villosus and Phyllanthus fraternus extracts on germinative capability of stored food grains. International Journal of Horticultural Science 25 (3-4): 7-10. https://doi.org/10.31421/IJHS/25/3-4/2914

Key words: bio-insecticides, food grains protectant, germination test, post-harvest, seed treatments, seed viability

\section{Introduction}

Seed availability in the developing nations heavily depends on the subsistence farmers' capacity to preserve the postharvest quality of their produce for consumption and seed purposes. These resource poor farmers usually preserve their food grains inside their own small storage facilities with little or no technological inputs thus predisposing it to high quantitative and qualitative losses due to insect infestation and damage.

Protection of stored grains from insect infestation is the major problem that concerns all nations in the world and it is important to search for good protective materials for the stored products against infestation. Seed treatment is an important process that provides insurance against insect pest infestation as well as soil-borne plant pathogens (Gwary et al., 2007). Throughout the world, seed treatments have relied mostly on the application of synthetic pesticides, which is still the most effective means of protection of stored food grains and other agricultural produces from insect and pathogenic infestation. In spite of being effective as seed treatment, many disadvantages related to the use of synthetic pesticides have been reported by several researchers (Srivastava \& Singh, 2002; Ileke, 2012). Therefore, there is a rising need for the development of unconventional strategies aiming at lessening the use of pesticides; amongst which are the use of botanicals. Previous studies have demonstrated the effect of plant products, though positive as seed treatments in suppressing pathogenic infection, insect infestation and damage, boosted seed germination, emergence and health of various crop plants (Rani \& Murthy, 2008; Rani \& Devanand 2011; Chukwuka et al., 2014). To be considered as a potential biocontrol agent, it is important that a plant product showing activity against insect pest or pathogen does not exhibit any phytotoxic effect on the seed viability or seedling vigour. Miafo et al., (2014) in a study observed that germination of cowpea seeds was unaffected after treatment with ethanolic leaf extracts of Balanites aegyptiaca, Melia azedarach and Ocimum gratissimum.

For the fact there are scanty literatures with regard to the effect of plant extracts used as seed protectants against insect infestation on seed germination and emergence compared to studies on seed borne pathogens, thus necessitate present study to evaluate the role of Mitracarpus villosus and Phyllanthus fraternus extracts in protecting seeds of some stored food grains from storage insects' effects on seed germinative quality. 


\section{Materials and methods}

\section{Experimental location}

The study was conducted at Insect Chemical Ecology Laboratory, Institute of Bioresources and Sustainable Development (IBSD), Imphal, Manipur, India (Latitude $24^{\circ}$ $49^{\prime} \mathrm{N}$ and Longitude $93^{\circ} 57^{\prime} \mathrm{E}$ ) under ambient conditions of $27 \pm 2{ }^{\circ} \mathrm{C}, 70 \pm 5 \%$ R.H and at photoperiod of 10:14 (L:D).

\section{Collection of plant materials}

Matured leaves of Mitracarpus villosus (Girdlepod Family: Rubiaceae) and Phyllanthus fraternus (Gulf leaf-flower Family: Euphorbiaceae) were collected from fallow farmland within the Teaching and Research Farms, Rufus Giwa Polytechnic, Owo, Ondo State, Nigeria (Latitude $7^{\circ} 11^{\prime} \mathrm{N}$ and Longitude $5^{\circ} 35^{\prime} \mathrm{E}$ ). Identification of the plant materials was carried out at the Forestry and Wood Technology Department of the Polytechnic where specimen vouchers were deposited. The plant materials were air dried for a week and thereafter milled to powder using hammer mill and packaged in a polythene bag till further used.

Hundred grams $(100 \mathrm{~g})$ of powdered M. villosus and $P$. fraternus was sequentially extracted with $500 \mathrm{ml}$ solvents of increasing polarity viz., petroleum ether, hexane, ethyl acetate, acetone, chloroform and methanol, in a soxhlet apparatus. The extracts were concentrated in rotary evaporator (Rotavapor RIIA (Buchi) Switzerland) under low pressure, below $60^{\circ} \mathrm{C}$ to make it solvent free (Pati \& Chowdhury, 2015). Chlorophyll removal from the dark-green residue was done by using activated charcoal. The chlorophyll free filtrate was then concentrated, and the solvent totally evaporated.

The dried residue was dissolved in a known volume of methanol on weight by volume (w/v) basis making it $100 \%$ stock solution and was stored in sealed glass vials and maintained in a refrigerator $\left(4^{\circ} \mathrm{C}\right)$ until further use (Murasing et al., 2017). The solution was assayed for insecticidal activity by the fumigant toxicity (Rajashekar et al., 2013). Active extract which showed maximum activity, was selected for the germination test.

\section{Seed viability and germination test}

Phytotoxicity of active extracts on seed viability, germination and seedling growth of wheat and green gram was assayed according to the reported procedure (Kirtane, 2018). Fifty (50) of each wheat and green gram seed samples were selected from wholesome seed lot and treated with 50, 100, 200 and $400 \mu \mathrm{g} / 1$ doses of active fractions of the various plant extracts. The treated seeds were then air dried and assayed for seed viability test at 24 and $72 \mathrm{~h}$ after treatment exposure time from which twenty grains of each seeds were randomly selected from each treatment and soaked in distilled water for about 30 mins, and kept on filter paper (Whatman No. 1) in a petri dish, moistened daily with distilled water and allowed to germinate at room temperature $\left(25 \pm 2^{\circ} \mathrm{C}\right)$. After 48 and $72 \mathrm{~h}$, germinated seeds were counted and percentage germination was calculated as follows: $\%$ of seed viability $=($ Number of seeds that germinated/Total number of seed sown) $x$ 100. Five replications each were made for the treatment and the control. Data collect was subjected to analysis of variance and treatment means were separated using Duncan Multiple Range Test at $5 \%$ probability level.

\section{Results and discussion}

\section{Effect of M. villosus and $P$. fraternus extract on seed viability and germination}

The bioactive compounds derived from the active fraction of $M$. villosus and $P$. fraternus extracts were observed to be effective in the conservation of the germinative power on the treated grains (Table 1-2). The seeds treated with $M$. villosus sub-active fraction extracts $\left(50-400 \mu \mathrm{g}\right.$ seed $\left.^{-1}\right)$ resulted in successful and normal germination within the range of 92.35 $96.83 \%$, irrespective of the extracts concentration; which is comparable with seeds in control (Table 1) that recorded 96.37 and $97.68 \%$ germination. Germination percentage in untreated seeds were not significantly different $(\mathrm{P}>0.05)$ compared to the treated seeds. Similar trend was equally observed in seeds treated with $P$. fraternus extracts with germination percentage ranging from $94.66-98.89 \%$ ), while seeds in control dishes recorded $95.55-100 \%$ germination (Table 2). Hence, it is evident from the observations that $P$. fraternus and $M$. villosus extracts did not impair or afflict any adverse effect on the germination capacity of green gram and wheat seeds. This shows that food grains treated with plant products maintain the seed quality while at the same time protecting seeds from stored beetle infestation and damage.

Table 1. Seed viability percentage of wheat and green gram treated with different concentrations ( $\mathrm{mg} / \mathrm{L})$ of $M$. villosus active fractions.

\begin{tabular}{lllll}
\hline \multirow{2}{*}{$\begin{array}{l}\text { Dosage } \\
\mu \mathrm{g} / \mathrm{l})\end{array}$} & \multicolumn{3}{c}{ \% germination (Mean $\pm \mathrm{SE})$} \\
\cline { 2 - 5 } & $24 \mathrm{~h}$ & $72 \mathrm{~h}$ & $24 \mathrm{~h}$ & $72 \mathrm{~h}$ \\
\hline 50 & $94.05 \pm 2.17^{\mathrm{a}}$ & $92.35 \pm 1.32^{\mathrm{a}}$ & $92.86 \pm 2.67^{\mathrm{a}}$ & $94.45 \pm 1.02^{\mathrm{a}}$ \\
100 & $94.50 \pm 1.45^{\mathrm{a}}$ & $93.55 \pm 2.27^{\mathrm{a}}$ & $92.36 \pm 1.33^{\mathrm{a}}$ & $94.16 \pm 2.67^{\mathrm{a}}$ \\
200 & $94.85 \pm 2.05^{\mathrm{a}}$ & $95.89 \pm 0.84^{\mathrm{a}}$ & $95.64 \pm 2.83^{\mathrm{a}}$ & $94.38 \pm 3.33^{\mathrm{a}}$ \\
400 & $93.76 \pm 2.86^{\mathrm{a}}$ & $96.83 \pm 1.05^{\mathrm{a}}$ & $94.48 \pm 2.23^{\mathrm{a}}$ & $93.15 \pm 2.14^{\mathrm{a}}$ \\
Control & $96.45 \pm 2.13^{\mathrm{a}}$ & $96.37 \pm 2.58^{\mathrm{a}}$ & $97.68 \pm 2.11^{\mathrm{a}}$ & $96.76 \pm 2.27^{\mathrm{a}}$ \\
\hline
\end{tabular}

Each value is a mean $\pm \mathrm{SE}$ of five replicates, means within the column followed by the same supper script(s) alphabet are not significantly different at $(\mathrm{P}>0.05)$ using Tukey's test.

Table 2. Seed viability percentage of wheat and green gram treated with different concentrations ( $\mathrm{mg} / \mathrm{L})$ of $P$. fraternus active fractions.

\begin{tabular}{lllll}
\hline \multirow{2}{*}{$\begin{array}{l}\text { Dosage } \\
\mu \mathrm{g} / \mathrm{l})\end{array}$} & \multicolumn{3}{c}{ \% germination $($ Mean $\pm \mathrm{SE})$} \\
\cline { 2 - 5 } & \multicolumn{2}{c}{ Wheat } & \multicolumn{3}{c}{ Green gram } \\
\cline { 2 - 5 } & $24 \mathrm{~h}$ & $72 \mathrm{~h}$ & $\mathrm{~h}$ & $72 \mathrm{~h}$ \\
\hline 50 & $95.55 \pm 0.17^{\mathrm{a}}$ & $98.95 \pm 1.72^{\mathrm{a}}$ & $94.66 \pm 0.76^{\mathrm{a}}$ & $98.45 \pm 2.02^{\mathrm{a}}$ \\
& & & & \\
100 & $96.50 \pm 0.25^{\mathrm{a}}$ & $98.15 \pm 1.72^{\mathrm{a}}$ & $94.82 \pm 1.56^{\mathrm{a}}$ & $97.31 \pm 1.84^{\mathrm{a}}$ \\
200 & $94.85 \pm 2.05^{\mathrm{a}}$ & $96.09 \pm 0.84^{\mathrm{a}}$ & $96.45 \pm 2.38^{\mathrm{a}}$ & $98.89 \pm 2.13^{\mathrm{a}}$ \\
400 & $95.44 \pm 1.36^{\mathrm{a}}$ & $97.35 \pm 1.11^{\mathrm{a}}$ & $96.39 \pm 1.05^{\mathrm{a}}$ & $98.55 \pm 0.25^{\mathrm{a}}$ \\
Control & $95.55 \pm 0.33^{\mathrm{a}}$ & $98.45 \pm 2.08^{\mathrm{a}}$ & $98.28 \pm 1.26^{\mathrm{a}}$ & $100.00 \pm 0.47^{\mathrm{a}}$ \\
\hline
\end{tabular}

Each value is a mean $\pm \mathrm{SE}$ of five replicates, means within the column followed by the same supper script(s) alphabet are not significantly different at $(\mathrm{P}>0.05)$ using Tukey's test.

\section{Discussion}

Seed storage is an essential post-harvest operation that decides the success of seeds in next generation (Ananthi et al., 2017). Higher vigour and viability are two characters that cannot be maintained in storage especially in food grains, since they deteriorate rapidly under ambient storage condition (Yaklich et al., 1979) due to insect pest infestation and other biotic factors that hasten the deteriorating rate of seed during storage (Renugadevi et al., 2006). Grains protectants play vital 
role in extending the storability of seeds to longer duration without appreciable loss in vigour and viability. As an ecofriendly and dual purpose treatment, plant products are widely used for seed treatment in the control of storage insect pests (Ananthi et al., 2017) and conservation of planting materials

Germination tests are used to evaluate the production of normal seedlings under optimal germination conditions (ISTA, 2014). The current study was steered in order to realize the effect of $M$. villosus and $P$. fraternus extracts seed treatments on germination and emergence of wheat and green gram. The results indicated that the plant extracts exhibited no adverse effects on seed germination and emergence.

The germinability of treated seeds and control observed through the standard germination test indicated that the seed germination was above $90 \%$ and the treatments showed no significant adverse effect on the seed viability and germination. The results revealed that, all the seed treatments were found to be effective in maintaining the quality of seed and in controlling the stored beetle infestation, as no abnormality was observed. This indicates that the plant extracts do not have any adverse effect on the seed viability; thus strengthens the nonphytotoxic nature of plant products. The findings conclude that the active fractions of the plant extracts used as grain protectants are comparatively safe for the grains stored for seed purposes owing to the higher seed emergence percentages recorded which could be attributed to the plant extracts insecticidal activities that are effective against some stored product insects. This aligned with Masangwa et al., (2017) who opined that for plant materials to be potential seed protectant, it is imperative that such a plant extract showing activity against insect pest and pathogen does not exhibit any phytotoxic effects on the seed. Similarly, the present study validates the findings of Gupta et al., (1991); Khaire et al., (1992); Gselase \& Getu (2009); Rani \& Devanand (2011); Mamun and Shahjahan (2011) Rajendra et al., (2014); Khinchi et al., (2017); Kongne et al., (2018); Danjumma et al., (2018) who all concluded that seeds treated with botanical powders and extracts proved to be more effective in the conservation of the germinative power of the treated seeds since all the seeds germinated successfully. Trematera et al., (1999) used Allium plants as grain protectant and observed no-adverse effect of these products on the viability of the treated grains. The observed no significant seed impairment recorded in this study may be due to the insecticidal properties and bioactive molecules present in the various plant materials which might have reduced the insect infestation and seed deterioration during storage (Schmidt et al., 1991). Renugadevi et al., (2006) opined that active principle $\beta$ asarone derived from Vasambu rhizome powder prevented bruchid infestation and maintained the viability of seeds and was also supported by Anandi (2001); Parameswari (2002); Ananthi et al., (2017).

It can be inferred that the germination test reveals that the plant extracts used for control of stored food grains insect pests in this trial did not show any visible negative effect on germination capacity of the seeds, thus strengthens the nonphytotoxic nature of plant products. Therefore, potential exploitation of $M$. villosus and $P$. fraternus as food grains protectant in insect pest management strategies is recommended for the resource poor farmers that store small amounts of food grains for consumption and planting. However, further investigations are suggested on biosafety and effects of the extracts on the organoleptic contents of the grains prior to consumption.

\section{Authors' contributions}

JM conceived, designed and carried out the experiment; RY conceived and supervised the experiment, carried out statistical analysis and interpretation of data; TI contributed to experiment conception and design, proofread the manuscript; MO participated in conception and design, coordinated the manuscript preparation; KD collections and review of literatures; TE sourced the plant materials and made same into powder. All authors read and approved the final manuscript.

\section{Acknowledgements}

The first author gratefully acknowledged The World Academy of Science (TWAS), Italy for the award of Research and Advanced Training Fellowship for the study.

\section{Conflict of Interest}

The authors have no conflict of interest to report.

\section{References}

Anandi, R., (2001): Seed technological studies in cowpea (Vigna unguiculata L. Walp) cv.CO 5. M.Sc (Ag.) Thesis, Tamil Nadu Agricultural University, Coimbatore, India.

Ananthi, M., Sasthri, G., Srimathi, P., Malarkodi, K. (2017) Bio-efficacy of plant products against insect infestation in green gram. Journal of Entomology and Zoology Studies. 5(4), 733-736.

Chukwuka, K. S., Obiakara, M., Ogunsumi, I. A. (2014): Effects of aqueous plant extracts and inorganic fertilizer on the germination, growth and development of maize (Zea mays L.). Journal of Agricultural Sciences (Belgrade). 59: 243-254

Danjumma, B. J., Majeed, Q., Yusuf, M., Peni, D. N. (2018): Effects of leaf powder of Citrus aurantifolia and Senna occidentalis on the development of maize weevil (Sitophilus zeamais Motschulsky, Coleoptera Curculionidae). Journal of Entomology and Zoology Studies. 6(2): 2216-2221.

Gselase, A., Getu, E. (2009): Evaluation of botanical plants powders against Zabrotes subfasciatus (Boheman) (Coleoptera: Bruchidae) in stored haricot beans under laboratory condition, African Journal of Agricultural Research. 4(10): 1073-1079.

Gupta, H. C., Bareth, S. S., Sharma, S. K. (1991) Bioefficacy of edible and non-edible oils against pulse beetle (Callosobruchus chinensis L.) on stored pulse and their effect on germination. Agriculture and Biological Research. 7: 101107.

Gwary, D. M., Ali, O., Gwary, S. D., (2007) Management of sorghum smuts and anthracnose using cultivar selection and seed dressing fungicides in Maiduguri, Nigeria. International Journal of Agriculture and Biology. 9: 324-328.

Ileke, K. D. (2012): Bioactivity of Anacardium occidentale (L) and Allium Sativum (L) powders and oil extracts against cowpea bruchid, Callosobruchus maculatus (Fab). International Journal of Biology. 4: 96-103.

International Seed Testing Association (2014): International Rules for Seed Testing, ISTA, CH-Switzerland.

Khaire, V. M., Kachare, B. V., Mote, U. N. (1992): Efficacy of different vegetable oils as grain protectants against pulse 
beetle, Callosobruchus chinensis Linn. in increasing storability of pigeon pea. Journal of Stored Products Research. 28: 153156.

Khinchi, K., Sharma, M. M., Khinchi, M. K., Naga, R. P., Acharya, D., Asiwal, R. C. (2017): Studies on efficacy of certain plant part powders against pulse beetle, Callosobruchus chinensis Linn. on chickpea, Cicer arietinum (L). Journal of Entomology and Zoology Studies. 5(3): 575-578.

Kirtane, S. A. (2018): Effect of Leaf Extract of Verbascum chinense (L.) Santapau on Seed Germination and Seedling Growth of Onion (Allium cepa L.). International Journal of Scientific Research in Science and Technology. 4(5): 18481852.

Kongne, M. L., Kouninki, H., Fameni, T. S., Fernand, N. T. F. (2018): Management of Callosobruchus maculatus F. (Coleoptera: Bruchidae) using methanol extracts of Carica papaya, Carissa edulis, Securidaca longepedonculata and Vinca rosea and impact of insect pollinators on cowpea types in the Far-North region of Cameroon. Journal of Entomology and Zoology Studies. 6(2): 1017-1027.

Mamun, M. S. A., Shahjahan, M. (2011): Effect of some indigenous plant extracts on the germination of wheat seeds. Bangladesh Journal of Agricultural Research. 36(4): 733-739.

Masangwa, J. I. G., Kritzinger, Q., Veling, T. A. S. (2017): Germination and seedling emergence responses of common bean and cowpea to plant extract seed treatments, Journal of Agricultural Science. 155: 18-31.

Miafo, A. P. T., Koubala, B. B., Bouba, D., Kansci, G. (2014) Preservation of cowpea (Vigna unguiculata) seeds: incidence of ethanolic extract from Balanites aegyptiaca, Melia azedarach and Ocimum gratissimum leaves on Callosobruchus maculatus (Coleptera: Bruchidae), Asian Journal of Agricultural Sciences. 6: 62-68.

Murasing, C., Das, P., Sathish, K., Hazarika, L. K. (2017): Bio efficacy of Ocimum sanctum L. (Lamiaceae) leaf extracts against Pulse beetle (Callosobruchus chinensis L.) (Coleoptera: Bruchidae) in stored green gram (Vigna radiate L.). Journal of Entomology and Zoology Studies. 5(4): 586-590.

Parameswari, K. (2002): Strategies to improve the seed production and shelf life of pigeonpea (Cajanus cajan L. mill sp.) hybrid COPH2. Ph. D Thesis. Tamil Nadu Agricultural University, Coimbatore, India.

Pati, U. K., Howdhury, A. (2015) A comparison of phytotoxic potential among the crude extracts from Parthenium hysterophorus L. extracted solvents of increasing polarity, International Letters of Natural Sciences. 33; 73-81.

Rajashaker, Y., Honnaiah, V. K., Ravindra, K. V., Bakthavatsalam, N. (2013): Isolation and characterization of biofumigant from leaves of Lantana camara for control of stored grain pests. Industrial Crops and Products. 51:224-228.

Rajendra, K. S., Shah, A., Ukala, D. N. (2014): Efficacy of plant extracts on the germination of wheat seeds. IOSR Journal Agriculture and Veterinary Science. 7(8): 72-76.

Rani, P. U., Devanand, P. (2011): Efficiency of different foliar extracts on grain protection and seed germination in maize, Research Journal of Seed Science. 4: 1-14.

Rani, P. U., Murthy, J. M. (2008): Botanical treatment for grain protection and their effects on seed germination and seedling performance of stored maize. Journal of Biopesticides. 1: $74-80$

Renugadevi, J., Natarajan, N., Rajasekaran, R., Srimathi, P. (2006): Bioefficacy of promising botanicals against insect infesting cowpea cv.CO 4. Indian Journal of Agricultural Research. 40(4): 262-266.

Schmidt, G. H., Risha, E. M., El-Nahal, A. K. M. (1991): Reduction of progeny of some stored product coleoptera by vapours of Acorus calamus oil. Journal of Stored Product Research.27(2): 121-127.

Srivastava, C., Singh, D. (2002): Study of phosphine resistance in Rhyzopertha dominica and Callosobruchus maculatus, Indian Journal of Entomology. 64: 377-378.

Trematera, P., Hanzotli, V. (1999): The activity of some compounds extracts of Allium on stored products insects Oryzaephilus surinamensis (L.), Sitophilus oryzae (L.) and Tribolium castaneum (H.). Anzeiger-Fur-Schandlingskuinde 72: $122-125$.

Yaklich, R. W., Kulik, M. M., Garrison, C. S. (1979): Evaluation of vigour in soybean seeds: Influence of date of planting and soil type on emergence, stand and yield. Crop Science. 19:242-246. 